\section{Summary of Conclusions}

Where an inequality of leg length of over $1 \frac{1}{2}$ in. is present or is to be anticipated one may arrive at the following conclusions.

1. Bone-shortening is the preferable approach to all cases with the exception of the few who are unwilling or who can ill afford to sacrifice any height.

2. Some surgeons seem far more willing to practise legshortening by epiphysiodesis than to attack an older patient by surgical bone-shortening, logically the equivalent operation for an older age group.

3. A very thorough technique is required in epiphysiodesis to avoid deformities, and a more extensive operation than that advocated by Phemister is therefore described.

4. Epiphysiodesis is often performed at too late an age for the desired results to be obtained.

5. Surgical bone-shortening is a safe procedure, and certain and quick in its results-considerable attributes in purely elective surgery.

6. Surgical bone-shortening is preferable in the femur, and two methods are advocated: (a) straightforward lateral overlap with transfixing screws; and $(b)$ excision of a segment below the lesser trochanter and fixation with a Blount plate.

7. Two further examples of a 4-in. femoral shortening with full return of knee movement and control within three to five months are reported.

In spite of the more challenging nature of leglengthening, an attempt has been made to demonstrate that leg-shortening has more to recommend it. Its adoption as the wiser procedure is advocated in most cases presenting with leg inequality sufficient to warrant surgery yet too old for treatment solely by epiphysial arrest.

\section{REFERENCES}

Abbott, L. C., and Saunders, J. B. de C. M. (1939). Ann. Surg., 110, 961 .

Barr, J. S. (1948). New Engl. J. Med., 238, 737.

Blount, W. P., and Clarke, G. R. (1949). J. Bone Jt Surg., 31A, 464.

Groves, E. W. Hey (1931). British Medical Journal, $2,1$.

Phemister, D. B. (1933). J. Bone Jt Surg., 15, 1.

Regan, J. M., and Chatterton, C. C. (1946). Ibid., 28, 265.

Straub, L. R., Thompson, T. C., and Wilson, P. D. (1945). Ibid., 27,254 .

White, J. Warren (1947): Ann. Surg., 125, 662.

Wilson, P. D., and Thompson, T. C. (1939). Ibid., 110, 992.

The New York Academy of Sciences, the fourth oldest scientific society in the United States-it was founded under a different name in 1817-recently elected a number of new foreign honorary life members, bringing the total of scientists so honoured in its 134 years of existence to 66. Among this latest addition to the roll were several medical men: Professor C. H. Best, of Toronto, co-worker of Banting in the first preparation of insulin and an authority on metabolism ; Dr. J. B. Collip, well known for his work on the parathyroids and mineral metabolism ; Sir Frank Burnet, of Melbourne, the great authority on virus diseases; and Professor Bernardo Houssay, of Buenos Aires, 1947 Nobel prize-winner in medicine and biology, who has worked on a wide front in endocrinology, and particularly on the pituitary in diabetes and on experimental hypertension. The other scientists were Professor W. T. Astbury, of Leeds (biophysicist), Professor Harold Jeffreys, of Cambridge (geophysicist and astronomer), Professor N. V. Sidgwick, of Oxford (organic chemist), Professor H. R. Kruyt, a Dutch physical chemist, Dr. Eduardo Cruz-Coke, a Chilean biochemist, and Professor J. Runnstrom, of Sweden, who has spent many years studying fertilization and early embryonic development in sea-urchin eggs.

\section{SIX BLOOD-GROUP ANTIBODIES IN THE SERUM OF A TRANSFUSED PATIENT}

\author{
BY
}

\author{
R. K. WALLER, M.D. \\ (From the Medical College of Virginia, Richmond, \\ Virginia, U.S.A.) \\ AND
}

R. R. RACE, Ph.D., M.R.C.S.

(From the Medical Research Council Blood Group Research Unit, Lister Institute, London)

The purpose of this note is to call attention to another instance of the formation of multiple blood-group antibodies after transfusion. The recipient was suffering from an undiagnosed collagen disease. The name "collagen disease" is conveniently used in the United States to denote a group of diseases, such as periarteritis nodosa and lupus erythematosus, which are of unknown aetiology but have certain common characteristics.

Sera containing multiple antibodies have twice before been reported. One of the donors was suffering from lupus erythematosus (Callender and Race, 1946) and the other from " osteosclerosis and extramedullary haematopoiesis" (Collins, Sanger, Allen, and Race, 1950).

\section{Case History}

The patient, a 30-year-old negro, was admitted to the Veterans Administration Hospital, Richmond, Va., on December 12, 1949, complaining of nausea, vomiting, and severe abdominal pain of about 12 days' duration. His illness began six years previously, and consisted then of migratory polyarthritis and serous pericarditis. A year later he was discharged from the Services, and at that time his skin and lips showed increased pigmentation. He had at one time suffered from exfoliative dermatitis subsequent to sulphonamide therapy. Ten months before admission he was in hospital for an undiagnosed condition which manifested itself by attacks of arthritis, angioneurotic oedema, endocrine dysfunctions, and gastro-intestinal irritability.

During the last few months he developed symmetrical, scaly, dry, pigmented lesions over the deltoid and infraclavicular regions.

It has not been possible to discover whether the patient was transfused during either of his stays in hospital: on neither occasion was he in a Richmond hospital.

Shortly after admission the patient was given three blood transfusions in one week (Table I) because of a severe hypochromic normocytic anaemia. - Five days after the third transfusion he was noticed to be severely jaundiced, and his urine was blood-stained. Approximately six weeks

TABLE I.-Transfusions of Patient

\begin{tabular}{|c|c|c|c|}
\hline No. & Date & Group of Donor & Reactions \\
\hline $\begin{array}{l}1 \\
2 \\
3\end{array}$ & $\begin{array}{c}\text { Dec. } 23,1949 \\
\text {," } 28 \\
\text { J0" 50 } \\
\text { Jan. } 5,1950\end{array}$ & $\begin{array}{l}\text { B, } \mathbf{R h +} \\
\mathbf{B}, \mathbf{R h}+ \\
\mathbf{B}, \mathbf{R h}+\end{array}$ & $\begin{array}{l}\text { Severe haemolytic } \\
\text { reaction }\end{array}$ \\
\hline $\begin{array}{r}4 \\
5 \\
6 \\
7 \\
8 \\
9 \\
10 \\
11\end{array}$ & $\begin{array}{c}\text { Feb. } 28 \\
\text { March } 8 \\
\text {," } 24 \\
\text { May } 10 \\
\text {, } 10 \\
\text {," 18 } \\
\text {, } 18\end{array}$ & $\begin{array}{l}\text { B, cDe/cde, S-* } \\
\text { B, cDe/cde, N, S- } \\
\text { B, cde/cde, S- } \\
\text { B, cDe/cde, N, S- } \\
\text { B, cde/cde, N, S- } \\
\text { O, cde/cde, N, S- } \\
\text { O, cde/cde, N, S- } \\
\text { O, cde/cde, N, S- }\end{array}$ & No reactions \\
\hline
\end{tabular}

* The absence of $\mathbf{S}$ was presumed from the compatible cross-match; no other anti-S serum was then available in Virginia. 
later it seemed advisable to transfuse the patient again, but by then it appeared impossible to cross-match him successfully. For this reason his blood was sent to one of us (R.K.W.). After identification of the various antibodies contained in the patient's serum he was transfused successfully several times.

Five months after admission he suffered the first of a series of three massive intestinal haemorrhages. From the first two he rallied, after transfusion, but during the third he died; this was about six and a half months after admission. Permission for a post-mortem examination could not be obtained.

During his stay in hospital the white cell count had varied from a leukaemoid level down to 2,000 per c.mm. . At no time were "lupus erythematosus inclusion bodies" found in the polymorphonuclear leucocytes.

\section{Summary of Serological Findings}

The patient belonged to group $\mathrm{B}, \mathrm{N}, \mathrm{cDe} / \mathrm{cde}$ or $\mathrm{cDe} / \mathrm{cDe}$ (Table II). Anti-M was the first antibody to be identified

TABLE II.-The Blood Groups of the Patient's Red Cells and the Antibodies in His Serum

\begin{tabular}{|c|c|}
\hline Patient's Groups & Antibodies in Serum \\
\hline $\begin{array}{l}\text { B } \\
\text { N, presumably } S- \\
\text { cDe/cde or cDe/cDe } \\
\text { Presumably } \mathrm{Fy}(\mathrm{a}-)\end{array}$ & $\begin{array}{l}\text { Anti-A } \\
\text { Anti-M and anti-S } \\
\text { Anti-C and anti-E } \\
\text { Anti-Fy }\end{array}$ \\
\hline
\end{tabular}

in his serum; it was clearly shown by tests in saline at $15^{\circ} \mathrm{C}$. Thereafter tests were confined to $\mathrm{N}$ blood samples. Titrations in saline at $37^{\circ} \mathrm{C}$. demonstrated the presence of anti-C. Because a sample of N S cde/cde blood was agglutinated the presence in the serum of anti-S was suspected; it was subsequently proved by tests on $\mathrm{O}$, cde/cde, $\mathrm{N}$ cells with and without the antigen $S$. The presence of anti-A could easily be demonstrated by an immediate reaction with $A$ cells on a tile.

A strongly positive reaction with $\mathrm{CDE} / \mathrm{CDE}$ cells suggested the presence of anti-E. This was proved by tests on saline suspensions of cells lacking $\mathrm{A}, \mathrm{M}, \mathrm{S}$, and $\mathrm{C}$ antigens, but some with and some without the antigen $E$. Those with $E$ were agglutinated, those without were not.

The shortage of available cells lacking the antigens $A$, $M, S, C$, and E made absorption necessary for the next stage. The serum was absorbed with blood $A_{1} B, M N S, P+, C D e /$ $\mathrm{CDe}, \operatorname{Lu}(\mathrm{a}-), \mathrm{K}-, \operatorname{Le}(\mathrm{a}-), \mathrm{Fy}(\mathrm{a}-)$, and, as this did not of course remove the anti-E, further tests were confined to blood samples lacking $\mathrm{E}$. Indirect antiglobulin tests then disclosed the presence of anti-Fya. This example of antiFya, unlike others so far described, is capable of giving weak reactions with Fy $(\mathrm{a}+)$ cells suspended in saline.

The following antibodies were not present in the serum: anti-B, - O, -H, -N, -P, -D, -d, -c, -e, - Lua , -K, -k, -Leb.

Once again it was rather disappointing that no "new" antibody could be found in the serum of a person obviously so apt to become immunized.

\section{Comment}

The possibility of a relationship between unusual ability to produce blood-group antibodies and certain diseases has been discussed in a previous paper (Collins et al., 1950). No conclusions were reached, and the conjectures will not be repeated here.

The serum described in this paper, which is from a person suffering from an undiagnosed collagen disease, is the third most abundant in blood-group antibodies to be reported. The other two sera were from patients suffering from lupus erythematosus diffusus and from osteosclerosis with extramedullary haematopoiesis respectively. Recovery was straightforward.

\section{Summary}

A patient who suffered from an undiagnosed collagen disease and who had received many transfusions was found to have the following blood-group antibodies in his serum: anti-A, -M, -S, -C, -E, and anti-Fya.

We wish to thank Dr. J. Kriz, chief of the Laboratory Service, Veterans Administration Hospital, Richmond, Va., for his kind co-operation in obtaining the clinical data of this case. We also wish to thank Mrs. M. Waller for the initial serological work-up. We are grateful to Dr. B. H. Kirman, of the Fountain Hospital, Tooting, for his help in setting up the large panel of donors of test cells without which such an investigation-as that here described is not possible.

\section{REFERENCES}

Callender, Sheila T., and Race, R. R. (1946). Ann. Eugen., Lond., 13, 102.

Collins, J. O., Sanger, Ruth, Allen, F. H., and Race, R. R. (1950). British Medical Journal, 1, 1297.

\section{Medical Memoranda}

\section{Double-barrelled Enteric Intussusception Causing Volvulus}

A number of unusual cases of intussusception were reported in the British Medical Journal of March 4, 1950 (page 525). Details of the following case may therefore be of interest.

\section{Case Report}

The patient, a girl aged 15, was admitted to hospital on February 25, 1950. In Novenber, 1949, after an attack of influenza, she had suffered from aching central abdominal pain for one hour, which was considerably relieved by vomiting twice. Fourteen days later she had severe "gripping" central abdominal pain for two hours, also relieved by vomiting. On two further occasions, at six-weeks intervals, she had similar but more severe attacks lasting four to five hours and six to seven hours respectively. Fourteen weeks after the first sign of trouble and two and a half days before admission the sequence started again, but this time did not cease. She was referred to hospital, where she had been seen once as an out-patient with "intestinal colic." The possibility of mesenteric adenitis, Meckel's diverticulum, or recurrent intussusception was then suggested, but was difficult to prove.

On examination the girl was not unduly distressed or dry. Her pulse was 108 , and respiration and temperature were normal. The abdomen was not rigid, but there was some tenderness and guarding in the subumbilical region and right iliac fossa. This area was filled with a diffuse soft swelling, in the centre of which was a firmer sausage-shaped mass 5-6 in. (12.5-15 cm.) long, running obliquely upwards to the right.

A provisional diagnosis of small-bowel obstruction probably due to intussusception was made, but it was. felt that there was something unusual about it and that this was probably not the whole story.

A right subumbilical paramedian incision was made, revealing the presence of sero-sanguineous exudate. A number of coils of dilated small gut were found "bunched " together in the pelvic brim region, which on further exploration proved to be a volvulus of ileum in a clockwise direction. On untwisting this the centre of the affected gut proved to be an entero-enteric intussusception, which seemed much more bulky and solid than would be expected, and which had a very tight neck, with foul purulent fluid exuding from beneath it when any endeavour was made to open it up. Attempted reduction by milking was unsuccessful. The 